\title{
Annual Report of the A.C.R.L. Executive Secretary, I949'50
}

This report covers the seven months (November I949-June 1950) during which I have been your executive secretary. Like other officers, I have been concerned with the general direction of the association and not slow in making recommendations to the Board of Directors. These matters are, however, the responsibility of the President and are at most briefly mentioned here.

\section{Membership}

The membership of the association increased from 4228 on Jan. I, I 949 , to 4649 on Jan. I, 1950. The great increases of previous years have fallen off; future growth will be made principally through increases in the usefulness of the Association's program.

The Office of Education Statistics of Libraries in Institutions of Higher Education, 1946-47 states that nearly 6000 professional librarians were employed in the I 340 institutions which reported. Allowances should be made for catalogers and other staff who may be interested in other divisions, for reference librarians in public libraries, for noninstitutional research libraries, for the 360 colleges which did not report, for the increase in number of professional librarians since 1946-47, and numerous lesser factors. $\mathrm{My}$ own guess is that we have a potential membership at this time of at least 8000 individuals and 2000 institutions. It seems fairly clear that our present membership is less than 50 per cent of what it ought to be.

It is all too apparent that some indi- viduals and the majority of institutions do not join A.C.R.L. because of error or thoughtlessness. About five eighths of the colleges and universities (belonging to A.L.A.) are members of no division, and among these are libraries headed by members taking active part in Association affairs. It is quite likely that errors and misunderstandings by business offices are responsible for nonfiling the necessary A.C.R.L. membership slips.

No extra charge is involved in joining A.C.R.L. at the same time as A.L.A. It is necessary to fill out and send in the A.C.R.L. slip as well as the A.L.A. slip. Head librarians are therefore urged to give personal attention to this if they wish 20 per cent of their A.L.A. dues to be allotted to the A.C.R.L. treasury. If only one half of all American college and university libraries belonged to A.C.R.L., our income would be increased 30-40 per cent; if all those which are now A.L.A. members (without any present divisional membership) joined A.C.R.L., our treasury would receive approximately $\$ 1600$ extra.

The A.C.R.L. office should do follow-up work on institutional memberships. The investment would return rich dividends; unfortunately no clerical help for this could be spared during the spring.

The Membership Committee has continued to do splendid work, the expense of which has been borne by the individual members.

\section{Finances of the Secretary's Office}

During the past year the executive secre- 
tary's office was allotted $\$ 9320$ on the A.L.A. budget. This covered salaries of two people and travel. It did not cover stationery, communications, and other direct (or any indirect) expenses which are lumped in with needs of other A.L.A. offices. This $\$ 9320$ came from A.L.A. and is distinct from the 20 per cent allotment of A.C.R.L. membership dues which went into our treasury.

About \$28,000 was paid in dues by A.C.R.L. members, I948-49. Of this, 20 per cent (about \$5750) went into our treasury. It thus appears that about $54 \mathrm{per}$ cent of each membership dollar went to direct A.C.R.L. purposes (A.C.R.L. office or treasury).

Essential work was neglected for lack of clerical assistance. I have asked the American Library Association for $\$ 2025.00$ additional on the office budget to begin Sept. I, 1950. If all this is granted, the level of A.C.R.L. support (per membership dollar) will be approximately 60 per cent and not out of line with support of the other principal divisions.

\section{College and Research Libraries}

College and Research Libraries, our official journal, continues to be the principal jewel in the Association crown. All credit belongs, of course, to the editorial board, led by Dr. Maurice Tauber. Subscriptions stood at 1964 in April 1950. This represents a gain of nearly 150 over April I949 (not counting 85 free subscriptions furnished to selected foreign libraries).

Revenue from advertising (October I949-July I950) is approximately $\$ 1600$.

About one third of the subscriptions are from nonmembers. As revenues from subscriptions and advertising increase, we come closer to the possibility of being able to finance (with treasury help) free subscriptions to members. This happy goal still seems fairly distant but by no means impossible.

\section{Field Work}

Visits have been made to nearly 70 libraries in 17 states. Most of this travel has been done since March and almost always in connection with trips required for other purposes. While the usefulness of these visits might better be reported by the institutions visited, I believe that nearly all were useful. At a number of institutions major problems were discussed at length with either the librarian or the president. These visits provide me with a fund of information otherwise not obtainable and uncover talent for Association work.

There seems to be an understandable but unnecessary reluctance on the part of libraries and library schools to request a visit by the executive secretary. This is particularly true of library schools which are usually very glad to have Headquarters people address their students. Since travel funds are provided for such purposes on the office budget, it is often possible to arrange a number of talks in an area and so make a long journey financially practical with small or no contribution from any one school, local library association, or library. On one trip of eight days' duration I gave eight talks, attended a state library conference, and visited I 5 libraries in four states. This was, of course, a tighter schedule than is normally practical since all travel of any distance was done after Io P.M., including one full night on a bus.

During the winter and spring I spoke to several local (Chicago and vicinity) library clubs. Trips were made to California, Texas, and Louisiana to address the college and university sections of the state associations at their annual conferences. These state and regional library meetings are excellent opportunities for meeting librarians who can seldom afford to attend national conferences. A number of informal talks were given to library school classes, staff associations, and other smaller groups. 
Topics of principal addresses were: "The Community Responsibilities of College and University Libraries;" "On Understanding the Reader as Well as the Book ;" "The Status of Research in College and University Librarianship;" "A.C.R.L.-Your Professional Association."

I attended the regional conferences at Grand Rapids and Fort Worth, which came just after my arrival at Headquarters.

Several short articles on college and research libraries were written for handbooks on colleges and other publications.

\section{Experimental Placement Program}

The experimental placement program, which was reported in the April issue of College and Research Libraries and at the Midwinter Meeting, was launched in April. It operates in South Carolina, North Carolina, Virginia (excluding District of Columbia suburbs), and eastern Tennessee. Experience in this limited area should indicate whether or not the plan is practical and worthy of extension. I hope the evidence will be clear in another six months. Great credit should go to the four representatives who took on this work; Mr. Rawlinson of the University of South Carolina, Mr. Christ of Duke, Mr. Dalton of the University of Virginia, and Miss Ryan of the University of Tennessee.

It is quite evident that the membership will greatly appreciate an effective, free placement service, and that we do not have the funds for salaried placement officers. The only solution is to spread the load sufficiently light to be borne by volunteers.

A good many members write that they are looking for new positions. Likewise some librarians send in notices of staff vacancies. I do what I can with such requests. In my traveling I meet many people and note any apparent special talents or abilities for placement or use on A.C.R.L. committees.

\section{Communications from Headquarters}

Now that our number has grown to nearly 5000, the use of an occasional mimeographed newsletter is impractical. The ideal is, of course, to make College and $R e$ search Libraries free to all. During the year ahead I hope that a communication from this office, written for College and Research Libraries, will be reprinted to form a brief quarterly newsletter for free distribution.

The logical channel for communications to members is the A.L.A. Bulletin, for which all of us pay. In the light of my experience it is not practical to count on the Bulletin to publish a communication, unless extremely brief, on reasonably short notice.

\section{Work with Sections and Committees}

During the past winter and spring there has been relatively little contact between Headquarters and committee chairmen. As you know, committees are authorized by the Board of Directors and appointed by the president (sectional committees by their chairman). I have been reluctant to press for information on progress of committee work, in the conviction that responsibility lay elsewhere and too much interest on my part might be misinterpreted as interference. I have worked closely with several committees.

The Headquarters office supplies membership lists to the sections and handles the mailing of ballots for those sections which have mail vote. These membership records require a sizeable amount of clerical work.

Newsletters sent out by the Junior College Libraries and Reference Librarians Sections were handled, partially or completely, in this office.

The real health of the association would seem to depend more on a wide spread of member participation and a steady production of useful research and investigation than on any other factors. I believe that 
these two aims can be accomplished by the devoted, regular work of a small planning group at the top and the assignment or suggestion of topics to section chairmen for committee work. The association can tap the energies and abilities of lesser-known members more easily through the sections than any other way. Every member ought to feel that his help, as well as dues, can be used and will be appreciated.

The paucity of study and investigation by the association on college library problems should be a matter of concern to the whole membership. Recommendations to remedy this situation have been prepared for the Board of Directors.

\section{Other Educational Associations}

Among the assigned duties of this office is that of representing college and reference library interests in the councils of leaders in higher education. There are many professional associations and therefore many conferences. No one person can attend a large number without devoting most of his time and a large amount of travel money to the purpose.

During the past seven months I attended only two such nonlibrary conferences (American Council on Education and N.E.A. Fifth Annual Conference on Higher Education). I hope to do somewhat better in the year ahead. Various A.C.R.L. members with special subject interests have represented A.C.R.L. officially at several other conferences. Generally speaking, our representation at national educational conferences has not been good. It could be improved considerably by more use of the special interests and contacts of members.

\section{Ceremonials}

The American Library Association has been unfailingly cooperative in turning over to me its invitations to be officially repre- sented at various institutional ceremonies, usually presidential inaugurations. Practice is to request some librarian who lives at not too great a distance to represent the Association. Many librarians have cooperated in this respect without the assistance of travel money. We should all be grateful to the elderly librarian who, in our behalf, sat through no less than 14 addresses at one inaugural.

Your secretary represented the American Library Association at the inauguration of President Millis of Western Reserve University in January.

\section{Foreign Visitors}

The A.C.R.L. office regularly assists librarians of foreign research libraries plan trips to American institutions, writes the necessary introductions, and assists these people in various other minor ways. These time-consuming obligations fall on your secretary as a division head in the American Library Association. Much as I would prefer to use time on other matters, there is no honest evading of this responsibility to international goodwill. It need hardly be added that contacts with these visitors are extremely pleasant and instructive.

\section{Information Services}

Requests for help on library problems are received daily. There is infinite variety to these. Some are so broad and general that adequate answer is impossible, as the request for a list of required reading books for the library (no further information), and the complaint that one problem which never seemed to be solved completely was the budget. Other queries are very specific but equally hard to answer.

In many cases the extensive vertical file material on hand produces some helpful data. In some cases I draw information from my own reading and experience, and in other cases the letters are referred to 
committee chairmen or other specialists.

Many letters request help on building problems. I acknowledge all these and refer them on to Dr. Robert H. Muller, chairman of the Committee on College and University Library Buildings. $\mathrm{He}$ has been a great help to many with building problems. I have leaned over backwards in answering all letters on any matter, whether or not later referred elsewhere.

By and large, this office can be of considerable assistance to small libraries. Its principal potential usefulness to large libraries is probably that of support before the administration. By this I mean we can endorse a projected program as sound, or send information that other important libraries have adopted the proposed policy, etc. Of course, there is an occasional request for endorsement of a program which seems ill-advised. So far, I have escaped from such requests without embarrassment.

It is extremely important to the work of the A.C.R.L. office that college and research libraries send in copies of useful documents. Principal types desired are annual reports, staff bulletins, or other publications which give data on changes of policy, and carbon copies of library policy statements of any description.

Other documents desired are: library handbooks, statements of rules and regulations, personnel codes, classification and pay plans, library statutes or other material on the government of the library, procedure manuals, new building plans, formal or informal library surveys, anything descriptive of interlibrary cooperation. This list might be extended.

Much of the usefulness of the A.C.R.L. office depends on its being able to furnish examples of how other libraries have handled a given situation. If more material is not sent in, I may be forced to send out a questionnaire.

\section{A.L.A.}

Your secretary is the head of an A.L.A. division and therefore takes part in staff conferences and other Headquarters enterprises. Cooperation at $50 \mathrm{E}$. Huron St. is good. A.L.A. staff members help me in many ways, and I endeavor to be equally cooperative. There is little logic and potential danger in being appointed by one body and paid by another, but no serious conflicts have arisen, thanks to the understanding of all concerned.

The past seven months have been happy working months for me. Our youthful traditions for frank expression and experimentation should be continued. We need more projects and more membership participation. Along this path should lie great accomplishments and vigorous growth for the association. 